

\section{ADB PROCUREMENT POLICY}

Goods, Works, Nonconsulting and Consulting Services 
(C) 2017 Asian Development Bank

6 ADB Avenue, Mandaluyong City, 1550 Metro Manila, Philippines

Tel +632632 4444; Fax +6326362444

www.adb.org

Some rights reserved. Published in 2017.

ISBN 978-92-9257-919-7 (Print), 978-92-9257-920-3 (e-ISBN)

Publication Stock No. TIM178817-2

http://dx.doi.org/10.22617/TIM178817-2

ADB does not guarantee the accuracy of the data included in this publication and accepts no responsibility for any consequence of their use. The mention of specific companies or products of manufacturers does not imply that they are endorsed or recommended by ADB in preference to others of a similar nature that are not mentioned.

By making any designation of or reference to a particular territory or geographic area, or by using the term "country" in this document, ADB does not intend to make any judgments as to the legal or other status of any territory or area.

This work is available under the Creative Commons Attribution-NonCommercial-NoDerivs 3.0 IGO license (CC BY-NC-ND 3.0 IGO) http://creativecommons.org/licenses/by-nc-nd/3.0/igo/. By using the content of this publication, you agree to be bound by the terms of this license. For attribution and permissions, please read the provisions and terms of use at https:/www.adb.org/ terms-use\#openaccess

This CC license does not apply to non-ADB copyright materials in this publication. If the material is attributed to another source, please contact the copyright owner or publisher of that source for permission to reproduce it. ADB cannot be held liable for any claims that arise as a result of your use of the material.

Please contact pubsmarketing@adb.org if you have questions or comments with respect to content, or if you wish to obtain copyright permission for your intended use that does not fall within these terms, or for permission to use the ADB logo.

Notes:

In this publication, “\$” refers to US dollars.

Corrigenda to ADB publications may be found at http://www.adb.org/publications/corrigenda 
I. Purpose

1. The purpose of this policy is to inform those carrying out a project ${ }^{1}$ that is financed in whole or in part by a loan from the Asian Development Bank (ADB), an ADB-financed grant, or by ADB-administered funds of the core principles that govern the procurement of goods, works, and nonconsulting and consulting services required for that project.

2. The financing agreement governs the legal relationships between the borrower $^{2}$ and $\mathrm{ADB}$, and the policy is applicable to the procurement of goods, works, and services ${ }^{3}$ for the project, as provided in the agreement. The rights and obligations of the borrower and the providers of goods, works, and services for the project are governed by the bidding documents, and by the contracts signed by the borrower with the providers of goods, works, and services and not by this policy or the financing agreements. No party other than the parties to the financing agreement shall derive any rights therefrom or have any claim to the proceeds of the financing.

\section{General Considerations}

3. This policy is derived from the Articles of Agreement of the Asian Development Bank Article 14, Operating Principle (xi), that ADB shall take the necessary measures to ensure that the proceeds of any loan made, guaranteed, or participated in by ADB are used only for the purposes for which the loan was granted, and with due attention to considerations of economy and efficiency.

4. The responsibility for the implementation of the project, and therefore for the procurement, award, and administration of contracts under the project, rests with the borrower. ADB, for its part, has the obligation to ensure that the proceeds of its financing are used with due attention to considerations of the core procurement principles mentioned herein.

The term "project" shall include technical assistance.

The term "borrower" as used in this policy includes recipients of ADB-financed grants and ADBadministered funds, and also refers to the executing agency for the ADB-financed project, in each case in the context of ADB's sovereign operations. Unless specifically stated, a borrower does not include a borrower under ADB's nonsovereign operations. In some cases, the borrower acts only as an intermediary and the project is carried out by another agency or entity, in which case references to the borrower include such agencies and entities, as well as sub-borrowers under onlending arrangements.

3 The term "services" shall include both nonconsulting and consulting services unless otherwise indicated. 


\section{Core Procurement Principles}

5. The specific procurement rules and procedures to be applied in implementation of a project depend on the circumstances of the particular case, but the following six core procurement principles ("Core Procurement Principles") guide ADB requirements:

(i) Economy. The principle of economy means taking into account factors such as price, quality, and any nonprice attributes, as appropriate, without adversely affecting the viability of the project.

(ii) Efficiency. The principle of efficiency ensures that procurement processes are proportional to the value and risks of the required outcome and underlying project activities, taking into account implementation capacity, time constraints, and cost-effectiveness.

(iii) Fairness. The principle of fairness means (a) equal opportunity for and treatment of eligible bidders; (b) equitable distribution of rights and obligations between borrowers and bidders; and (c) credible mechanisms for addressing procurement-related complaints and providing recourse. $A D B$ encourages open competition as the preferred procurement approach, whenever possible, to maximize fairness of the opportunity to bid.

(iv) Transparency. The principle of transparency means ensuring, through appropriate documentation and review of activities in the procurement process, that (a) relevant procurement information is made publicly available to interested parties, in a consistent and timely manner, through readily accessible and widely available sources at no (or reasonable) cost; (b) appropriate reporting of procurement activity; and (c) use of confidentiality provisions in contracts only where justified.

(v) Quality. This principle requires that the procurement arrangements ${ }^{4}$ are structured to procure inputs and deliver outputs of appropriate standard in a timely and effective manner to achieve the project outcomes and development objectives, taking into account the context, risk, value, and complexity of procurement.

(vi) Value for money. This principle enables the borrower to obtain optimal benefits through effective, efficient, and economic use of resources by applying, as appropriate, the Core Procurement

Procurement arrangements include procurement modalities and, as the context permits, the nature and extent of borrower responsibility and ADB oversight. 
Principles and related considerations, which may include lifecycle costs and socioeconomic and environmental development objectives of the borrower. Price alone may not sufficiently represent value for money.

\section{Fitness for Purpose}

6. Fitness for purpose requires procurement arrangements to appropriately reflect the strategic needs and circumstances of the situation. In case a standardized approach cannot effectively and efficiently meet project outcomes and development objectives, including in capacity-constrained environments, a customized approach may be adopted, entailing transaction-specific methods and documentation.

\section{Eligibility}

7. Except in any case in which the Board of Directors determines otherwise, (i) loans or grants from Special Funds resources can be used only for procurement of goods, works, and services produced in, and supplied from, developed member countries that have contributed to such resources or developing member countries; and (ii) loans or grants from ADB's ordinary capital resources or ADB-administered funds can be used only for procurement of goods, works, and services produced in, and supplied from, member countries.

8. ADB permits bidders from all eligible countries to offer goods, works, and services for $A D B$-financed projects. For a contract to be financed in whole or in part by $A D B$, any participation conditions shall be limited to those that are essential to ensure the bidder's capability and resources to successfully perform the contract in question.

\section{Development of Domestic Industry}

9. $\mathrm{ADB}$ encourages the development of domestic contracting, consulting, and manufacturing industries in the country of the borrower. 


\section{Integrity}

10. ADB requires application of the highest standard of ethics during any procurement process subject to this Policy and use of funds, resources, assets, and authority in accordance with ADB's Anticorruption Policy and Integrity Principles and Guidelines (both as amended from time to time) (Anticorruption Guidelines).

\section{Conflict of Interest}

11. ADB considers a conflict of interest to refer to situations in which a party has interests that could improperly influence that party's performance of official duties or responsibilities, contractual obligations, or compliance with applicable laws and regulations. A conflict of interest may not, in all cases, in and of itself, constitute a violation of ADB's Anticorruption Guidelines, if appropriately addressed or mitigated.

\section{Accountability}

12. The concept of accountability, as it applies to ADB and borrowers, combines the requirements of transparency and responsibility, holding those involved in the procurement process accountable for their actions (or inactions).

\section{Noncompliance}

13. If the borrower or other parties involved in the procurement process do not comply with the applicable procurement requirements, $A D B$ may, in addition to the contractual remedies set out in the relevant financing agreement, take appropriate actions consistent with ADB's implementation support and monitoring and fiduciary role.

\section{Complaints}

14. Procurement-related complaints may be brought to the attention of the borrower or ADB, or both, at the appropriate stage of the procurement process. They must be addressed objectively and in a timely manner, with transparency and fairness. 


\section{Alternative Procurement Arrangements}

15. ADB may agree to (i) apply the procurement rules and procedures of another multilateral or bilateral agency or organization involved in the project, and may agree to such a party taking a leading role in providing implementation support and monitoring project procurement activities; or (ii) rely on the procurement rules and procedures applied by an agency or entity of the borrower accredited by ADB, provided that in each case such arrangements are (a) compatible with the value, risk, or complexity of the procurement; (b) consistent with the Core Procurement Principles; and that (c) unless waived, ADB's member country eligibility restrictions continue to apply; and (d) ADB's Anticorruption Guidelines and contractual remedies in applicable financing agreements with the borrower continue to apply.

16. For cases where ADB relies on procurement risk assessments carried out by another development partner, ADB shall be satisfied with the quality of such assessments, and associated fiduciary risks and mitigation measures that have been established.

\section{E-procurement}

17. To facilitate transparency and efficiency in the procurement process, ADB encourages borrowers to continually modernize their procurement systems, including procurement through electronic means (e-procurement).

\section{Procurement Plan}

18. The procurement plan describes how the project procurement activities support the development objectives of the project and deliver value for money under a risk-managed approach. The scope and details of the procurement plan take into account, and are proportional to, the relevant market, scale, risk, value, and country circumstances, including, when applicable, situations of urgent need of assistance or capacity constraints, and the specific economic, environmental, and social objectives of the project.

19. The procurement plan sets forth (i) the particular contracts for the goods, works, and/or services required in carrying out the project; (ii) the proposed methods for procurement of contracts that are permitted under the financing agreement; (iii) the types of bidding 
documents to be used; and (iv) the related ADB review procedures and proposed contract supervision arrangements.

20. The borrower prepares and furnishes the procurement plan to ADB as part of project preparation, and this is to be confirmed by ADB before loan negotiations. The borrower updates the procurement plan annually or as needed throughout the duration of the project. Any changes or modifications to a procurement plan by a borrower are subject to ADB concurrence. ADB publicly discloses the initial procurement plans (and any subsequent updates), indicating the general scope and value of procurement for the coming year.

\section{$\mathrm{XV}$. Procurement for Nonsovereign Operations}

21. In the case of procurement contracts to be financed by ADB under its nonsovereign operations from the proceeds of (i) an ADB loan, (ii) a loan guaranteed by ADB, or (iii) a grant to a private sector recipient, procurement shall be carried out following established private sector or commercial practices acceptable to ADB. 


\section{About the Asian Development Bank}

ADB's vision is an Asia and Pacific region free of poverty. Its mission is to help its developing member countries reduce poverty and improve the quality of life of their people. Despite the region's many successes, it remains home to a large share of the world's poor. ADB is committed to reducing poverty through inclusive economic growth, environmentally sustainable growth, and regional integration.

Based in Manila, ADB is owned by 67 members, including 48 from the region. Its main instruments for helping its developing member countries are policy dialogue, loans, equity investments, guarantees, grants, and technical assistance. 